УДК: 519.81

Олександр Юрійович Пермяков (доктор технічних наук, професор) ${ }^{1}$

Наталія Олександрівна Королюк (кандидат технічних наук) ${ }^{2}$ Софія Олександрівна Маслійова ${ }^{2}$

${ }^{1}$ Національний університет оборони Украӥни імені Івана Черняховського, Київ, Украӥна

${ }^{2}$ Харківський національний університет Повітряних Сил ім. І. Кожедуба, Харків, Украӥна

\title{
ПІДХІД ЩОДО АВТОМАТИЗАЦІї ПРОЦЕСІВ ОЦІНКИ ПОВІТРЯНОГО ПРОТИВНИКА НА ПУНКТАХ УПРАВЛІННЯ ПОВІТРЯНИХ СИЛ ЗСУ
}

У статті запропонований підхід щзодо вдосконалення спеціального математичного $i$ програмного забезпечення АСУ для вирішення задачі розпізнавання замислу повітряного противника на основі нових інформаційних технологій створення та використання баз знань. Розглядається процес розпізнавання замислу дій повітряного противника в якості слабо структурованої задачі, яка стоїть перед особою, щзо приймає рішення, в ході підготовки та веденні бойових дій. Обгрунтовано для рішення слабо структурованої задачі використання теорії нечітких множин, щзо дозволяє розв'язати задачу розпізнавання замислу дій повітряного противника у складі системи підтримки прийняття рішення. В якості базової моделі представлення знань процесів розпізнавання варіантів дій повітряного противника в умовах невизначеності обтрунтована нечітка множина типу 2 i заснована на ній нечітка логічна система, щзо дозволяє формалізувати завдання, які не піддаються суворої формалізації $і$ мають логіко-аналітичний характер. Використання когнітивних методів при створенні баз знань забезпечує можливість засобам автоматизаџії щуодо рімення задачі оцінки повітряного противника в цілому, $i$ зокрема задачі розпізнавання варіантів його дій, яка обмежується в основному технічними характеристиками обчислювальних засобів.

Ключові слова: розпізнавання замислу повітряного противника, нечітка множина типу 2, нечітка логічна система, система підтримки прийняття рішення.

Вступ

Постановка проблеми. Аналіз локальних військових конфліктів останнього десятиліття двадцятого і початку двадцять першого століть дозволяє зробити висновок, що вдосконалення системи протиповітряної оборони (ППО) України $\epsilon$ в даний час однією 3 важливих завдань військового будівництва. В ході ведення бойових дій однією 3 вирішальних умов організації та успішного проведення ППО об'єктів, своїх військ $\epsilon$ обгрунтоване і своєчасне прийняття рішень на застосування сил і засобів за результатами оцінки повітряного противника (ПП). При цьому в ході ведення бойових дій основним змістом оцінки противника $€$ аналіз даних про повітряну обстановку, що надходять 3 вищестоящого пункту управління (ПУ), від підлеглих і взаємодіючих військ, зіставлення цих даних з раніше зробленими прогнозами і передбачення змін в обстановці.

Процес оцінки і розпізнавання ПП в ході ведення бойових дій можна умовно розділити на оцінку противника на підступах до об'єктів, що обороняються, оцінку противника, діючого в межах відповідальності підпорядкованих сил і засобів авіації і ППО, і оцінку противника після відбиття ударів або в проміжках між ними. Основним питанням оцінки ПП на підступах до об'єктів, що обороняються, є розпізнавання варіанту дій противника. Важливість достовірного i оперативного розпізнавання варіантів дій ПП визначається тим, що результат розпізнавання $є$ основою для прийняття рішення особою, що приймає рішення (ОПР), на введення того чи іншого варіанту дій своїх військ.

У той же час, зростаюча динамічність i швидкоплинність бойових дій, високий ступінь невизначеності обстановки, жорсткі часові рамки розпізнавання варіантів дій ПП і необхідність аналізу і врахування великої кількості різнорідних чинників свідчать про необхідність підвищення рівня автоматизації процесу вирішення задач розглянутого класу.

Аналіз спеціального математичного i програмного забезпечення як існуючих комплексів засобів автоматизації (КЗА) КП Повітряних Сил (ПС) дозволяє стверджувати, що процеси розпізнавання варіантів дій ПП автоматизовані недостатньо.

В ході нанесення удару 3 повітря, противник намагається досягнути певної мети. Метою може бути зміна політичного спрямування влади в країні-об'єкті удару, порушення ії територіального суверенітету, реалізація економічних інтересів тощо. Мета визначається органами державного та військового управління противника на етапі формування замислу операції i, відповідно, являється визначеною для противника та невизначеною для сторони, по якій завдається удар. Оскільки мета операції (бойових дій) багато 
в чому буде визначати форми $\mathrm{i}$ засоби застосування військ противника та об'єкти його удару, розпізнавання цієї мети якомога раніше є важливим завданням для органів управління ППО держави. Це дозволить зменшити рівень невизначеності відносно варіанта замислу дій ПП, та дасть можливість вибрати раціональний варіант дій своїх військ (сил) щодо прикриття від ударів 3 повітря тих об'єктів, по яким буде наноситись удар, й своєчасно визначити (уточнити) завдання підпорядкованим військам.

Аналіз останніх досліджень і публікацій. Розробці та використанню інтелектуальних інформаційних технологій для автоматизації процесів управління та створення відповідних Б3 присвячений цілий ряд робіт [1-4]. Однак питання розробки i використання методів формалізації, консолідації знань процесів розпізнавання варіантів дій ПП в умовах невизначеності $\epsilon$ недостатньо дослідженими.

Таким чином, проблема полягає у пошуку методів розпізнавання замислу дій ПП, у знаходженні логічних закономірностей діяльності органів управління, які дозволять розпізнати об‘єкти удару, а 3 них знайти можливі варіанти ієрархії цілей дій ПП, які розкривають його замисел.

Метою статті є удосконалення підходів щодо визначення закономірностей, що зв'язують сукупність розпізнаних об'єктів повітряного удару 3 ієрархічними цілями операції (бойових дій), які на підставі аналізу розвідувальних даних розкриють замисел дій ПП.

\section{Виклад основного матеріалу дослідження}

Розпізнавання замислу дій ПП $є$ найбільш складною та слабо структурованою задачею, яка стоїть перед ОПР в ході підготовки та веденні бойових дій. На теперішній час ii рішення лежить в площині емпіричних знань людини, що на основі отриманої різнорідної інформації і власного досвіду та інтелекту, викриває замисел його дій. Однак, розвиток методів штучного інтелекту для рішення слабо структурованих задач, а також використання теорії нечітких множин дозволило реалізувати задачу розпізнавання замислу дій ПП у складі системи підтримки прийняття рішення (СППР).

Побудова повітряного угрупування противника здійснюється у відповідності з відомими законами збройної боротьби, виходячи з обраної мети удару та порядку досягнення даної мети. Саме тому розпізнавання мети дій засобів повітряного нападу (ЗПН) противника зводиться до визначення порядку його дій, виходячи з відомої інформації, яка може бути отримана різними засобами з різних джерел. Для ОПР важливо, щоб ця інформація була заданого рівня достовірності, але це не завжди можливо забезпечити.

Прийняття рішення щодо розпізнавання замислу дій ПП відноситься до класу задач прийняття рішення в умовах природної i поведінкової невизначеності. Природна невизначеність передбачає аналіз подій, які не носять масового характеру, тому не можуть бути описаними імовірнісними законами, а ситуації, що розглядаються при підготовці й прийнятті рішень, як правило, є унікальними. Такі ситуації, явища та події необхідно враховувати при прийнятті рішення, тому що застосування детермінованих методів теорії дослідження операцій може привести до значних помилок.

Таким чином, при організації процесу управління виникає протиріччя між необхідністю обробки інформації з нестохастичною (природною i поведінковою) невизначеністю та відсутністю ефективних методів іiі обробки для забезпечення прийняття рішень, що спрямовані на раціональне виконання поставлених бойових задач. Отже, в процесах підготовки й прийняття рішень виникає задача - розроблення методики розпізнавання замислу дій ПП $з$ застосуванням СППР, яка дозволить приймати раціональні за ефективністю бойових дій рішення 3 врахуванням існуючих ресурсних обмежень на ведення бойових дій.

Це призводить до того, що розпізнавання здійснюється або тільки на основі суб'єктивних оцінок ОПР або 3 використанням результатів розв'язання окремих інформаційно-розрахункових завдань, що не дозволяють в повному обсязі врахувати складність динамічної повітряної обстановки. При цьому результати аналітичної роботи відповідних органів управління на етапі планування бойових дій в алгоритмах КЗА не враховуються. Забезпечення необхідного рівня автоматизації процесів розпізнавання варіантів дій ПП утруднено і тим, що в ході бойової роботи ОПР використовують в основному власні знання i досвід, які важко формалізуються. Одним 3 перспективних напрямків автоматизації процесів вироблення рішень $є$ вдосконалення спеціального математичного і програмного забезпечення АСУ на основі нових інформаційних технологій. До таких технологій належать i інтелектуальні інформаційні технології створення та використання баз знань (БЗ) КЗА [5-7]. Б3 КЗА являють собою сукупність правил, фактів, механізмів виведення і програмних засобів, що описує деяку предметну область і призначені для подання накопичених в ній знань [7]. Одним 3 найбільш складних i основоположних етапів технології створення БЗ $є$ етап формалізації i консолідації знань в заданій предметній області.

Використання когнітивних методів при створенні Б3 КЗА забезпечує такі можливості засобів автоматизації, завдяки яким рішення задач оцінки ПП в цілому, і зокрема задач розпізнавання варіантів його дій, обмежується в основному технічними характеристиками обчислювальних засобів. Спеціальне математичне i програмне забезпечення в КЗА 3 використанням Б3 відрізняється високим ступенем адаптивності до зовнішніх умов, здатністю до самонавчання, 
реалізації функцій самоорганізації складних систем, що дозволяє розширити коло, автоматизовано розв'язуваних, завдань при оцінці ПП. Функції ОПР в таких системах полягають в формалізації і введенні в БЗ КЗА експертних знань на етапі підготовки КЗА до функціонування, а також у формулюванні директив і норм системи, що регламентують іiї поведінку.

Процес створення БЗ повністю визначається обраним методом представлення знань, тобто сукупністю методів і засобів опису, розміщення, зберігання i модифікації знань [7]. Метод представлення знань являє собою сукупність взаємозалежних способів формального опису знань і маніпулювання цими описами. Розрізняють дві групи методів представлення знань: декларативні і процедурні.

В основі когнітивних методів, використовуваних для автоматизації завдань управління, використовуються відповідні моделі подання знань. Модель представлення знань - це сукупність правил подання, опису та породження знань в БЗ. Моделі подання знань діляться на два типи: логічні та евристичні. Логічні моделі дозволяють уявити знання про завдання логікоаналітичного, розрахункового i пошукового характеру. Однак ряд істотних недоліків (немає суворої процедури підбору аксіом для організації логічного висновку, не завжди $є$ можливість отримання результату рішення; наявність невизначеності вихідної інформації не дозволяє організувати логічний висновок на формалізованих структурах знань) обмежують їх застосування для представлення процесу оцінки дій ПП. Евристичні моделі (мережеві, фреймових і продукційні) мають більш різноманітний набір засобів, що передають специфічні особливості предметної області, але також не дозволяють враховувати невизначеність (нечіткість) вихідних даних.

Останнім часом більшого практичного застосування знаходять моделі подання знань, засновані на нечітких множинах і нечіткої логіки [4,5]. Нечіткі множини i нечітка логіка використовуються для формалізації задач, які чинять спротив суворої формалізації, що мають логіко-аналітичний характер, а в якості вхідних

\section{Jimepamypa}

1. Alimpiev A. Selecting a model of unmanned aerial vehicle to accept it for military purposes with regard to expert data Eastern-European. Journal of Enterprise Technologies. 2017. Vol. 1, No. 9(85). P. 53-60. 2. Даник Ю.Г., Пермяков О.Ю. Сучасні інформаційні технології в забезпеченні національної безпеки і оборони. Сучасні інформаційні технології у сфері безпеки і оборони. 2018. C.159-174. 3. Command and Control of Joint Air Operations. Joint Publication/3-3010, February 2014. 4. Королюк Н.О., Першин О.В., Грідньова Т.О., Шевченко С.О. Обгрунтування сучасного підходу щодо автоматизації процесів прийняття рішень по управлінню авіацією. Збірник наукових пращь. 2019. №1(59). С.32-39. або вихідних даних мають невизначені (нечіткі) дані [5].

В даний час, в рамках дослідження математичного апарату нечітких множин та нечіткої логіки, одним 3 найбільш актуальних $\epsilon$ питання, пов'язані з вивченням різних узагальнень нечітких множин, які забезпечували б формалізацію більшої кількості додаткових ступенів невизначеності в порівнянні 3 класичними нечіткими множинами (нечіткими множинами типу 1 (НMT1)). За останнє десятиліття подальший розвиток в даній області отримали перш за все нечіткі множини типу 2 (НМТ2). Таким чином, в якості базової моделі представлення знань процесів розпізнавання варіантів дій ПП в умовах невизначеності визначимо НМТ2 і засновані на них нечіткі логічні системи (НЛС) інтервального типу 2 (НЛС IT2).

\section{Висновки й перспективи подальших досліджень}

Таким чином, одним 3 основних етапів оцінки ПП в ході ведення бойових дій $є$ розпізнавання варіантів його дій при відбитті ударів. Невизначеність і динамічність повітряної обстановки, тимчасові обмеження, значні обсяги інформації, що характеризують дії ПП, які не задані чітко і $є$ суперечливими, зумовлюють зростання вимог до рівня обгрунтованості та оперативності розпізнавання варіантів дій ПП на ПУ Повітряних Сил. Одним 3 напрямків виконання вимог $\epsilon$ автоматизація процесів розпізнавання. При цьому перспективним напрямком підвищення рівня автоматизації оперативності та достовірності розпізнавання $\epsilon$ використання інтелектуальних інформаційних технологій. На даний момент відсутні методи формалізації знань в досліджуваній предметній області, що, в свою чергу, визначає необхідність вдосконалення технології, яка забезпечила б виконання вимог щодо засобів формалізації знань, засобів програмної реалізації Б3.

В якості моделі представлення знань процесів розпізнавання варіантів дій ПП в умовах невизначеності визначені НМТ2 і засновані на них НЛС IT2, що дозволяють формалізувати завдання, що не піддаються суворої формалізації і мають логіко-аналітичний характер.

5. Королюк Н.О. Корольов Р.В, Коршець О.А. Процедура формалізації даних, які використовуються при описі процесу управління рухом повітряних об'єктів. Збірник наукових праџь ХНУПС. 2017. № 4(53). С.103-106. 6. Камінський В.В., Тюрін В.В., Камінський В.В., Корщець О.А., Королюк Н.О. Аналіз застосування безпілотних літальних апаратів в сучасних збройних конфліктах та АТО на Сході України. Наука $і$ оборона. 2017. № 3(4). С.4-8. 7. Субботин С.А., Олейник А.А., Гофман Е.А. Интеллектуальные информационные технологии проектирования автоматизированных систем диагностирования и распознавания образов: монографія. Харьков: ООО «Компания Смит». 2016. 317 с. 


\title{
ПОДХОД ПО АВТОМАТИЗАЦИИ ПРОЦЕССОВ ОЦЕНКИ ВОЗДУШНОГО ПРОТИВНИКА НА ПУНКТАХ УПРАВЛЕНИЯ ВОЗДУШНЫХ СИЛ ВСУ
}

\author{
Александр Юрьевич Пермяков (доктор технических наук, профессор) ${ }^{1}$ \\ Наталья Александровна Королюк (кандидат технических наук) ${ }^{2}$ \\ София Александровна Маслиева ${ }^{2}$
}

\author{
${ }^{1}$ Национальный университет обороны Украины имени Ивана Черняховского, Киев, Украина \\ ${ }^{2}$ Харьковский национальный университет Воздушных Сил имени И.Кожедуба, Харьков, Украина
}

В статье предложенный подход по совершенствованию специального математического $и$ программного обеспечення АСУ для решения задачи распознавания замысла воздушного противника на основе новых ин-формационных технологий создания и использования баз знаний. Рассматривается проиесс распознавания замысла действий воздушного противника в качестве слабо структурированной задачи, которая стоит перед лицом, принимающим решение, в ходе подготовки и ведения боевых действий. Обоснованно для решения слабо структурированной задачи использование теории нечетких множеств, что позволяет решить задачу распознавания замысла действий воздушного противника в составе системы поддержки принятия решения. В качестве базовой модели представления знаний процессов распознавания вариантов действий воздушного противника в условиях неопределенности обосновано нечеткое множество типа 2 и основана на ней нечеткая логическая система, что позволяет формализовать задания, которые не поддаются формализации и имеют логикоаналитический характер. Использование когнитивных методов при создании баз знаний обеспечивает возможность средствам автоматизации помогать решению задачи распознавания вариантов действий противника, которая ограничивается в основном техническими характеристиками вычислительных средств.

Ключевые слова: распознавание замысла воздушного противника, нечеткое множество типа 2 , нечеткая логическая система, система поддержки принятия решения.

\section{APPROACH ON THE AUTOMATION OF AIRCRAFT OWNER'S EVALUATION PROCESSES AT THE POINTS OF MANAGEMENT OF THE AIR FORCE}

\author{
Aleksandr Permakov (Doctor of technical sciences, Professor) ${ }^{1}$ \\ Natalia Korolyuk (Candidate of technical sciences, associate professor) ${ }^{2}$ \\ Sofia Masliova ${ }^{2}$ \\ ${ }^{1}$ National defence University of Ukraine named after Ivan Chernyakhovsky, in Kiev, Ukraine \\ ${ }^{2}$ Kharkiv national Air Forces named after I. Kozhedub, Kharkiv, Ukraine
}

In the article offered approach in relation to perfection of special mathematical and programmatic за-безпечення ASC for the decision of task of recognition of intention of air opponent on the basis of new informative technologies of creation and use of bases of knowledge. The process of recognition of to intention actions of air opponent is examined as the poorly structured task, that stands before a person that makes decision, during preparation and conduct of battle actions. Reasonably for a decision poorly of task of the use of theory of fuzzy sets, that allows the to untie task of recognition of intention of actions of air opponent in composition the system of support of decision-making. As a base model of representation of knowledge of processes of recognition of variants of actions of air opponent in the conditions of vaguenesses a fuzzy set is reasonable as 2 and the unclear logical system is based on her, that allows to formalize tasks that does not yield severe formalization and have analytical character. Using of logical methods for creation of bases of knowledge provides possibility to facilities of automations in relation to the decision of task of estimation of air opponent on the whole, and in particular tasks of recognition of his actions, that is limited to mainly technical descriptions of computing facilities.

Keywords: recognition of intention of air opponent, fuzzy set as 2, unclear logical system, system of support of decision-making.

\section{References}

1. Alimpiev A. Selecting a model of unmanned aerial vehicle to accept it for military purposes with regard to expert data Eastern-European. Journal of Enterprise Technologies. 2017. Vol. 1, 9(85). R. 53-60. 2. Danyk Ju.Gh., Permjakov O.Ju. Suchasni informacijni tekhnologhiji $\mathrm{V}$ zabezpechenni nacionaljnoji bezpeky i oborony. Suchasni informacijni tekhnologhiji u sferi bezpeky $i$ oborony. 2018. S.159-174. 3. Command and Control of Joint Air Operations. Joint Publication/3-3010, February 2014. 4. Koroljuk N.O., Pershyn O.V., Ghridnjova T.O., Shevchenko S.O. Obghruntuvannja suchasnogho pidkhodu shhodo avtomatyzaciji procesiv pryjnjattja rishenj po upravlinnju aviacijeju. Zbirnyk naukovykh pracj. 2019. №1(59). S.32-39.

5. Koroljuk N.O. Koroljov R.V, Korshecj O.A. Procedura formalizaciji danykh, jaki vykorystovujutjsja pry opysi procesu upravlinnja rukhom povitrjanykh ob'jektiv. Zbirnyk naukovykh pracj KhNUPS. 2017. 4(53). S.103-106. 6. Kaminsjkyj V.V., Tjurin V.V., Kaminsjkyj V.V., Korshhecj O.A., Koroljuk N.O. Analiz zastosuvannja bezpilotnykh litaljnykh aparativ v suchasnykh zbrojnykh konfliktakh ta ATO na Skhodi Ukrajiny. Nauka $i$ oborona. 2017. 3(4). S.4-8. 7. Subbotyn S.A., Olejnyk A.A., Ghofman E.A. Yntellektualjnye ynformacyonnye tekhnologhyy proektyrovanyja avtomatyzyrovannykh system dyaghnostyrovanyja y raspoznavanyja obrazov: monoghrafija. Kharjkov: OOO «Kompanyja Smyt». 2016. $317 \mathrm{~s}$. 